\title{
Energy consumption reduction strategy for freezing of packaged food products
}

\author{
Maíra de Paula GONÇALVES ${ }^{1 *}$, Vivaldo SILVEIRA JUNIOR ${ }^{2}$
}

\begin{abstract}
In this work, a model of the process of freezing strawberries placed in boxes using forced air tunnel was studied. A strategy of operating condition modification in each stage of the process (pre-cooling, freezing step and sub-cooling) was applied, in a simulated process, regarding air temperature change. Time and energy consumption behaviors due to air temperature conditions in the tunnel were evaluated for each stage. Air temperature at different process stages affected both process times and system thermal demands. Operating conditions for each stage, which provided the best system global performance, were chosen, aiming energy consumption reduction without damaging product final quality, once each stage minimum requirements were taken into account. The strategy proposed produced an energy economy of 5.9\%, comparing to the traditional process using constant temperatures, and it showed potential to be applied in different products and equipment with appropriate changes in the methodology.
\end{abstract}

Keywords: freezing; energy economy; forced convection; packaged food products.

Practical Application: Freezing of foodstuff, with modified temperature conditions, aiming energy economy.

\section{Introduction}

Freezing is a food preservation process based on reducing product temperature below its freezing point, aiming the inhibition of deteriorating reactions, both microbiological and biochemical, due to not only temperature lowering but also to water activity decrease, which comes from ice crystals growth. Such process is divided in three stages: pre-cooling, where only sensible heat is removed; freezing step, where most of the free water solidifies; and sub-cooling, where almost all of the heat removed is sensible and the frozen food product stabilizes. The majority of the ice crystals are formed at freezing step (Zaritzky, 2000). The presence of big ice crystals damages the food product structure, and the crystals sizes depend on the heat transfer rate during the freezing step, so the final product quality may be controlled by the time it remains at this stage (Fellows, 2006).

The freezing process of food products is greatly complex, since it depends on a series of factors, such as product shape, and also composition and thermo-physical properties, which vary thru the freezing, since they depend on food's free water solute concentration, which increases as the amount of ice crystals rises (Heldman, 1992). Therefore, estimating a food product's freezing rate is something highly complex, so most industrial operations work with overdimensioned processes, aiming to ensure product quality, and leading to higher energy consumption.

Aiming to reduce energy consumption, strategies involving refrigeration systems optimization have been studied, especially considering that the systems are usually dimensioned for a higher load than the one truly used. Lago (2016) studied the effects of using a variable speed compressor and an electronic expansion valve in a refrigeration system, operating with R-134a vapor compression, comparing to a constant speed system, getting lower consumption levels when intermediate compressor speeds were used. Salvador (1999) studied the energetic performance of an industrial refrigeration system, operating with ammonia vapor compression, for freezing food products with forced air, using evaporation temperatures varying in function of the thermal load, but without considering quality aspects of the frozen product; an energy economy of around $4 \%$ was obtained when operating with full thermal load, and $8 \%$ when operating with partial thermal load.

Thus, the aim of this work is to propose and evaluate a strategy of operating conditions change in a tunnel freezing process, using process modeling and simulation, by modifying the air temperature in each step of the process, considering the requirements of each one of them, so an energy consumption reduction can be obtained, keeping the predicted conditions for product quality maintenance.

\section{Material and methods}

\subsection{Product properties and modeling}

The products, fresh strawberries, were modeled as spheres with diameter of $2.5 \mathrm{~cm}$, disposed in three boxes vertically piled (as shown in Figure 1), whose dimensions were considered to be $58.5 \times 40.0 \times 12.5 \mathrm{~cm}$, with a $9.0 \mathrm{~cm}$ high strawberry layer. For calculation purposes, the strawberries were considered 
to be disposed in a face-centered-cubic structure (CFC). Therefore, 5280 strawberries were considered in the three boxes, totalizing $43196 \mathrm{~cm}^{3}$.

The strawberries thermo-physical properties were estimated, for each different temperature involved in the process, considering fresh strawberries centesimal composition, according to the Food Centesimal Composition Table (Universidade Estadual de Campinas, 2011). The estimation of product properties was made taking into account process stages delimited by the following temperatures: product initial temperature of $15^{\circ} \mathrm{C}$; freezing step initial temperature of $-1.02{ }^{\circ} \mathrm{C}$; freezing step final temperature of $-4.02{ }^{\circ} \mathrm{C}$; product final temperature of $-18{ }^{\circ} \mathrm{C}$.

The estimated thermo-physical properties at each temperature are shown at Table 1.

\subsection{Specific heat capacity}

The specific heat capacity per mass unit, due to temperature decrease and phase change in each process stage, was determined by Equations 1, 2 and $3\left(Q_{\text {pre }}, Q_{\text {freez }}\right.$ e $Q_{\text {sub }}$, respectively) (Pham, 1984).

$Q_{\text {pre }}=c_{u, \text { mean }}\left(T_{i}-T_{m}\right)$

$Q_{\text {freez }}=\Delta H_{\text {sol }}$

$Q_{\text {sub }}=c_{f, \text { mean }}\left(T_{m}-T_{f}\right)$

where $T_{m}$ is the mean freezing temperature $\left(-2.52{ }^{\circ} \mathrm{C}\right), T_{i}$ is product's initial temperature $\left(15^{\circ} \mathrm{C}\right), T_{f}$ is product's final temperature $\left(-18^{\circ} \mathrm{C}\right), c_{u \text {,mean }}$ is the mean specific heat at unfrozen state $\left[\mathrm{J} \mathrm{kg}^{-1} \mathrm{~K}^{-1}\right], \Delta \mathrm{H}_{\text {sol }}$ is solidification enthalpy $\left[\mathrm{J} \mathrm{kg}^{-1}\right]$ and $c_{\text {f,mean }}$ is the mean specific heat at frozen state $\left[\mathrm{J} \mathrm{kg}^{-1} \mathrm{~K}^{-1}\right]$.

The volumetric heat capacities for each stage were calculated multiplying Equations 1 to 3 by the mean between initial and

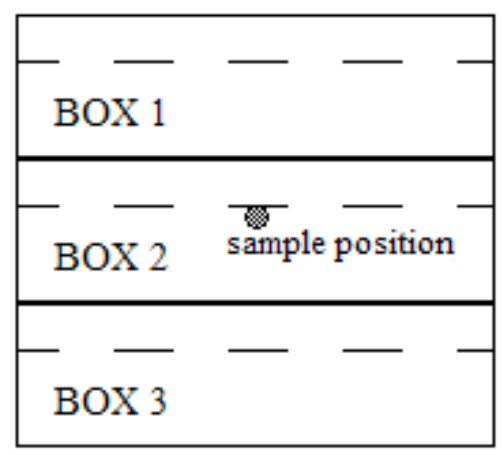

Figure 1. Frontal view of the considered disposition of boxes and sample at the freezing forced air tunnel. final density at the stage. Total heat capacities for each stage were determined multiplying the volumetric heat capacities by product's total volume.

\subsection{Convective heat transfer coefficients}

The convective heat transfer coefficients were calculated, for each air temperature used, considering a sample placed at the upper portion of the middle box, and constant inlet air flow rate of $2000 \mathrm{~m}^{3} \mathrm{~h}^{-1}$. A contact surface area of $0.09 \mathrm{~m}^{2}$ and a hydraulic diameter of $0.08 \mathrm{~m}$ were considered, so the air velocity at the studied position was $7.33 \mathrm{~m} \mathrm{~s}^{-1}$.

The choice of the middle box (box number 2) was made arbitrarily, once preliminary studies, using actual boxes disposed as the ones modeled in the present work, pointed that convective coefficients did not show significant variance between the boxes.

The Reynolds number was calculated by Equation 4:

$$
\operatorname{Re}=\frac{\rho_{\text {air }} \cdot v \cdot D_{h}}{\mu_{\text {air }}}
$$

where $\rho_{\text {air }}$ is air density $\left[\mathrm{kg} \mathrm{m}^{-3}\right]$ and $\mu_{\text {air }}$ is air viscosity [Pa s], both at air mean temperature, $v$ is the air velocity at the studied position $\left[\mathrm{m} \mathrm{s}^{-1}\right]$ and $D_{h}$ is the hydraulic diameter $[\mathrm{m}]$.

The Nusselt number was calculated using the equation obtained by Resende (2001), for equipment and boxes set with the same dimension of the ones considered in the present work (Equation 5).

$N u=0.01575 \cdot R e^{0.81439}$

Finally, the convective heat transfer coefficient $(h)$ was calculated by Equation 6 .

$h=\frac{N u \cdot k_{\text {air }}}{D_{h}}$

where $k_{\text {air }}$ is air thermal conductivity at air mean temperature $\left[\mathrm{W} \mathrm{m} \mathrm{m}^{-1} \mathrm{~K}^{-1}\right]$.

\subsection{Process times}

The process times were calculated by Pham's freezing time prediction model (Pham, 1984), for pre-cooling $\left(t_{\text {pre }}\right)$, freezing step $\left(t_{\text {freez }}\right)$ and sub cooling $\left(t_{\text {sub }}\right)$ (Equations 7, 8 and 9, respectively).

$\mathrm{t}_{\text {pre }}=\frac{\mathrm{Q}_{\mathrm{v}} \cdot \mathrm{V}}{\mathrm{h} \cdot \mathrm{A} \cdot\left[\left(\mathrm{T}_{\mathrm{i}}-\mathrm{T}_{\text {air }}\right)-\left(\mathrm{T}_{\mathrm{m}}-\mathrm{T}_{\text {air }}\right)\right]} \cdot \ln \frac{\mathrm{T}_{\mathrm{i}}-\mathrm{T}_{\text {air }}}{\mathrm{T}_{\mathrm{m}}-\mathrm{T}_{\text {air }}} \cdot\left(1+\frac{\mathrm{Bi}}{6}\right)$

Table 1. Product thermo-physical properties at different process temperatures.

\begin{tabular}{|c|c|c|c|c|}
\hline $\mathrm{T}\left({ }^{\circ} \mathrm{C}\right)$ & 15.00 & -1.02 & -4.02 & -18.00 \\
\hline Frozen water fraction & 0.00 & 0.00 & 0.66 & 0.80 \\
\hline Specific heat at frozen state $\left(\mathrm{J} \mathrm{kg}^{-1} \mathrm{~K}^{-1}\right)$ & - & - & 1674 & 1674 \\
\hline Solidification enthalpy $\left(\mathrm{kJ} \mathrm{kg}^{-1}\right)$ & - & - & 300.16 & 300.16 \\
\hline Specific heat at unfrozen state $\left(\mathrm{J} \mathrm{kg}^{-1} \mathrm{~K}^{-1}\right)$ & 3924 & 3921 & - & - \\
\hline Density $\left(\mathrm{kg} \mathrm{m}^{-3}\right)$ & 1051 & 1052 & 1005 & 996 \\
\hline Thermal conductivity $\left(\mathrm{W} \mathrm{m} \mathrm{m}^{-1} \mathrm{~K}^{-1}\right)$ & 0.55 & 0.53 & 1.18 & 1.53 \\
\hline
\end{tabular}


$\mathrm{t}_{\text {freez }}==\frac{\mathrm{Q}_{\mathrm{v}} \cdot \mathrm{V}}{\mathrm{h} \cdot \mathrm{A} \cdot\left(\mathrm{T}_{\mathrm{m}}-\mathrm{T}_{\text {air }}\right)}\left(1+\frac{\mathrm{Bi}}{4}\right)$

$\mathrm{t}_{\text {sub }}=\frac{\mathrm{Q}_{\mathrm{v}} \cdot \mathrm{V}}{\mathrm{h} \cdot \mathrm{A} \cdot\left[\left(\mathrm{T}_{\mathrm{m}}-\mathrm{T}_{\text {air }}\right)-\left(\mathrm{T}_{\mathrm{f}}-\mathrm{T}_{\text {air }}\right)\right]} \ln \frac{\mathrm{T}_{\mathrm{m}}-\mathrm{T}_{\text {air }}}{\mathrm{T}_{\mathrm{f}}-\mathrm{T}_{\text {air }}} \cdot\left(1+\frac{\mathrm{Bi}}{6}\right)$

where $Q_{v}$ is the volumetric heat capacity $\left[\mathrm{J} \mathrm{m}^{-3}\right], V$ is the product volume $\left[\mathrm{m}^{3}\right], h$ is the convective heat transfer coefficient [W $\left.\mathrm{m}^{-2} \mathrm{~K}^{-1}\right], A$ is the heat transfer area $\left[\mathrm{m}^{2}\right], T_{i}$ is product's initial temperature $[\mathrm{K}], T_{\text {air }}$ is air temperature $[\mathrm{K}], T_{m}$ is the mean freezing temperature $[\mathrm{K}], B i$ is the Biot number $[-]$ and $T_{f}$ is product's final temperature $[\mathrm{K}]$.

The Biot number $(B i)$ was calculated by Equation 10 .

$B i=\frac{h \cdot D_{h}}{k}$

where $D_{h}$ is the hydraulic number of one unit of product [m] and $k$ is the mean between initial and final thermal conductivities at the stage $\left[\mathrm{W} \mathrm{m} \mathrm{m}^{-1} \mathrm{~K}^{-1}\right]$.

\subsection{Equipment modeling}

The compressor of the refrigeration system was modeled considering the operating properties, as provided by the manufacturer, of a semi-hermetic reciprocating compressor, with 4 cylinders, volumetric displacement of $76.6 \mathrm{~m}^{3} \mathrm{~h}^{-1}$ and rotation speed of $1450 \mathrm{rpm}$, operating with R-404a. The compressor yield, or volumetric efficiency $\left(\lambda_{v}\right)$, and inefficiency $(I)$ were calculated, from equipment data sheet information on cooling capacity and power consumption, regarding the operating regime, by Equations 11 and 12.

$\lambda_{v}=\frac{Q \cdot v_{e v}}{V_{t} \cdot \Delta h_{e v}}$

$I=P-\frac{V_{t} \cdot \Delta h_{c p}}{v_{e v}}$

where $Q$ is the cooling capacity [W], $v_{e v}$ is the refrigerant specific volume at the evaporator outlet $\left[\mathrm{m}^{3} \mathrm{~kg}^{-1}\right], V_{t}$ is the theoretical volume displaced by the compressor $\left[\mathrm{m}^{3} \mathrm{~s}^{-1}\right], \Delta \mathrm{h}_{e v}$ is evaporation specific enthalpy variation $\left[\mathrm{J} \mathrm{kg}^{-1}\right], P$ is the electric power consumption [W] e $\Delta \mathrm{h}_{c p}$ is compression specific enthalpy variation $\left[\mathrm{J} \mathrm{kg}^{-1}\right]$.

The volumetric efficiencies and inefficiencies were calculated for evaporating temperatures of $-5,-10,-15,-20,-25,-30,-35,-40$ e $-45^{\circ} \mathrm{C}$, with constant condensing temperature of $30^{\circ} \mathrm{C}$. From these values, equations were obtained, in function of the compression rate.

The values for specific volume, enthalpy and compression rate were obtained by R-404a state diagrams from the software CoolPack ${ }^{\circledast}$.

As for ventilation, a fan with nominal air flow rate of $2000 \mathrm{~m}^{3} \mathrm{~h}^{-1}$ and nominal power consumption of $180 \mathrm{~W}$ was simulated.

\subsection{Energy consumption simulation}

At first, the thermal load to be removed was determined ( $q$ - Equation 13) for each simulated situation, considering the volumetric heat capacities calculated for each stage $\left(Q_{v o l}\right)$, product total volume $(V)$ and the time elapsed to complete each stage $(t)$.
$q=\frac{Q_{v o l} \cdot V}{t}$

Then, compressor volumetric efficiency and inefficiency were calculated for each temperature - considering the evaporating temperature $6{ }^{\circ} \mathrm{C}$ below the required air mean temperature. The compressor cooling capacity $(Q)$ and electric power consumption (P) were obtained for each situation, simulating $100 \%$ compressor load operation, by Equations 14 and 15.

$Q=\frac{\lambda_{v} \cdot V_{t} \cdot \Delta h_{e v}}{v_{e v}}$

$P=I+\frac{V_{t} \cdot \Delta h_{c p}}{v_{e v}}$

where $\lambda_{v}$ is compressor's volumetric efficiency [-], $V_{\mathrm{t}}$ is the theoretical volume displaced by the compressor $\left[\mathrm{m}^{3} \mathrm{~s}^{-1}\right], \Delta \mathrm{h}_{e v}$ is evaporation specific enthalpy variation $\left[\mathrm{J} \mathrm{kg}^{-1}\right], v_{e v}$ is the refrigerant specific volume at the evaporator outlet $\left[\mathrm{m}^{3} \mathrm{~kg}^{-1}\right]$, $I$ is compressor's inefficiency [kW] e $\Delta \mathrm{h}_{c p}$ is compression specific enthalpy variation $\left[\mathrm{J} \mathrm{kg}^{-1}\right]$.

From these values, the percentage required use of the compressor was determined ( $Q \%$ - Equation 16), regarding the maximum nominal cooling capacity.

$Q \%=\frac{q}{Q}$

The electric power consumption for each simulated situation $\left(P_{\text {comp }}\right)$ was calculated by Equation 17, considering that the compressor operating conditions were the same used for the full charge operation.

$P_{\text {comp }}=P \cdot Q \%$

Once $P$ was calculated taking system inefficiency into account, and $P_{\text {comp }}$ was calculated considering that all operational conditions used in $P$ determination were kept unchanged, Equation 17 was taken as valid for the studied system.

The compressor energy consumption for each simulated situation ( $E_{\text {comp }}-$ Equation 18$)$ was calculated regarding the time required for the stage to be complete.

$E_{\text {comp }}=P_{\text {comp }} . t$

The total energy consumption was calculated by the sum of compressor energy consumption and the fan energy consumption (180 W multiplied by the time required).

\section{Results and discussion}

\subsection{Choice of appropriate conditions for each stage}

For this analysis, the air temperatures were estimated respecting the limits defined for each stage: from -5 to $-40{ }^{\circ} \mathrm{C}$ for pre-cooling, from -10 to $-40{ }^{\circ} \mathrm{C}$ for freezing step and from -20 to $-40{ }^{\circ} \mathrm{C}$ for sub-cooling.

For comparison purposes, the global process under a single constant temperature for all three stages was simulated. For this case, air temperatures were considered between -20 and $-40^{\circ} \mathrm{C}$. 
The results are illustrated in Figure 2, which shows curves relating process time and total energy consumption in function of the air temperature, for each process stage and the global process.

Taking into account only the total energy consumption of each stage, the condition which would provide the minimization of this variable would be the one with the highest air temperature. A difference of $6^{\circ} \mathrm{C}$ to the final stage temperature was considered to be the limit condition for the heat exchange to happen. Hence, the maximum possible temperatures for each stage were defined: $-7^{\circ} \mathrm{C}$ for pre-cooling, $-10^{\circ} \mathrm{C}$ for freezing step and $-24^{\circ} \mathrm{C}$ for sub cooling.

If these operating conditions were used, the energy consumption would be the lowest, and equal to $2.27 \mathrm{~kW} \mathrm{~h}$, with process time of $146.9 \mathrm{~min}$.

Figure 2 graphs shows the existence of points which combine short process time and low energy consumption, at the crossing between time and consumption curves, although a minimum point does not exist.

Observing these points, approximate air temperatures at the crossing condition were obtained: $-14^{\circ} \mathrm{C}$ for pre-cooling, $-17^{\circ} \mathrm{C}$ for freezing step, $-24^{\circ} \mathrm{C}$ for sub-cooling and $-27^{\circ} \mathrm{C}$ for the global process at constant conditions.

A process using modified conditions per stage, at the defined crossing conditions $\left(-14 /-17 /-24^{\circ} \mathrm{C}\right)$, would take $79.0 \mathrm{~min}$ to be complete, with an energy consumption of $2.46 \mathrm{~kW}$ h; while the global process using a single constant condition, at its crossing condition $\left(-27 /-27 /-27^{\circ} \mathrm{C}\right)$, would take $46.9 \mathrm{~min}$, with an energy consumption of $2.98 \mathrm{~kW} \mathrm{~h}$.

In this case, the process using modified conditions per stage $\left(-14 /-17 /-24^{\circ} \mathrm{C}\right)$ would take a time $68.5 \%$ longer to be complete, but would provide a decrease of $17.3 \%$ in energy consumption.

Thus, the simulation results showed the process condition which provided the best performance, considering the combination of time and energy consumption. If applied in an industrial context, such condition would allow the economy of both energy and time.

\subsection{Considerations on economy and product quality}

When working with food processes, it is necessary to verify the compatibility between situations which promote economy and the ones which provide quality and safety to the final product. Hence, it is important to emphasize that the definition of operating conditions must be done based on the characteristics of each process.

The freezing step is the critical stage of a freezing process, because most of the free water in the product solidifies at such stage, and the time it takes determines the ice crystals sizes, and, therefore, the quality of the final product. Accordingly, using

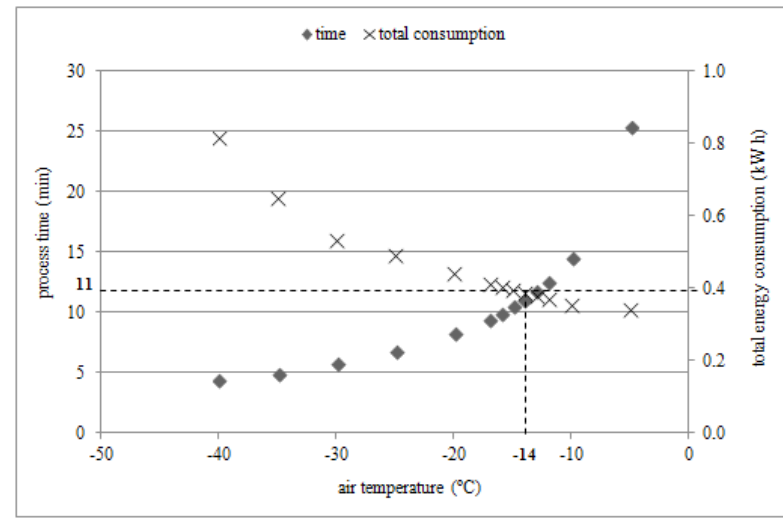

(A)

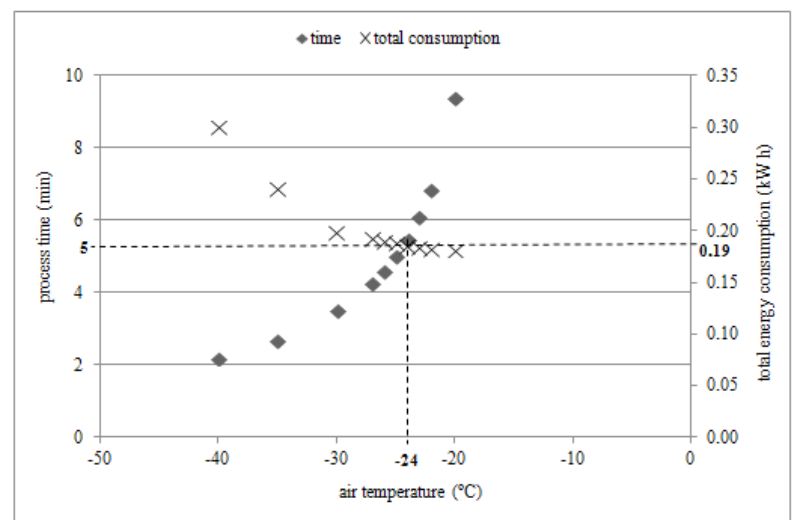

(C)

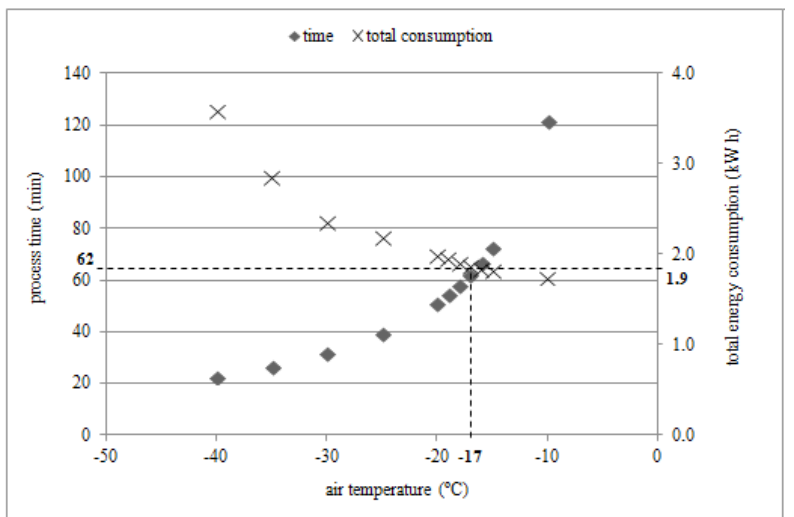

(B)

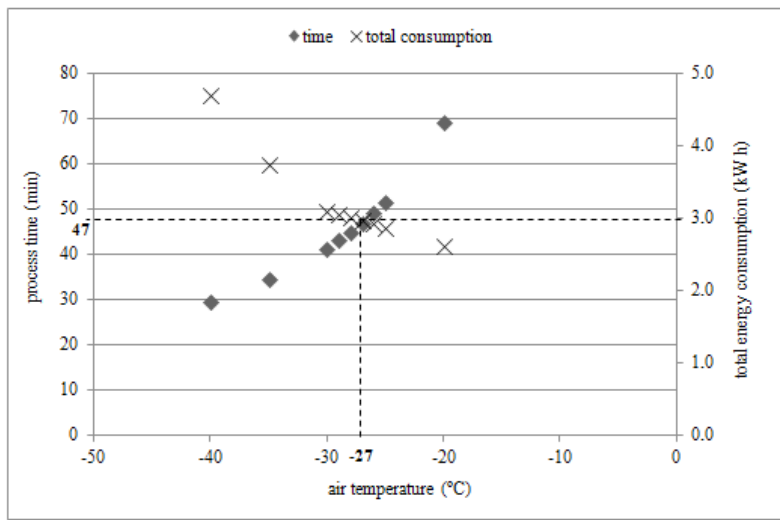

(D)

Figure 2. Curves of process time and total consumption versus air temperature regarding (A) pre-cooling; (B) freezing step; (C) sub-cooling; (D) global process using constant conditions. 
a shorter time at this stage, at the expense of higher energy consumption, may be advantageous.

On the other hand, the pre-cooling does not require that much care, since the product is completely unfrozen at this stage, and temperatures around $0{ }^{\circ} \mathrm{C}$ are considered enough for reducing the temperature of fresh fruit (Teruel, 2008). So, the temperatures considered in this work are already low enough, and an investment in energy economy can be made in this stage, at the expense of increasing the process time.

As to the sub-cooling, since most of the ice crystals are already formed when the stage begins, there is no need to keep the air temperature at the lowest levels, allowing energy economy.

Considerations made, five different processes were proposed, as shown in Table 2 and Figure 3. The processes at minimum consumption conditions (Ref. $1 ;-7 /-10 /-24^{\circ} \mathrm{C}$ ) and at crossing conditions (Ref. $2 ;-14 /-17 /-24^{\circ} \mathrm{C}$ ) were used as reference.

For the sub-cooling, the minimum consumption condition and the crossing condition happen at the same temperature of $-24^{\circ} \mathrm{C}$, which was considered adequate for the stage requirements, and kept in all proposed processes.
For the pre-cooling, both crossing and minimum consumption conditions were simulated $\left(-14\right.$ and $-7^{\circ} \mathrm{C}$, respectively).

For the freezing step, the crossing temperature, $-17^{\circ} \mathrm{C}$, was kept at Process $1\left(-7 /-17 /-24^{\circ} \mathrm{C}\right)$, although it doesn't sufficiently fit the stage requirements. For this stage, the minimum temperature of -27 was also simulated, once it is in accordance with industrial usual freezing processes.

The proposed processes were compared with the global process at constant conditions $\left(-27 /-27 /-27^{\circ} \mathrm{C}\right)$. The percentage variations obtained for each stage are shown in Table 3.

The best results, regarding energy consumption, were seen at processes in which the pre-cooling happened at $-7^{\circ} \mathrm{C}$. By considering the requirements of the freezing step, however, Process $1\left(-7 /-17 /-24^{\circ} \mathrm{C}\right)$ was eliminated. Thus, Process 3 , which uses $-27^{\circ} \mathrm{C}$ as freezing step temperature, was considered the best option.

The representative behavior histories of both air and product temperatures, for the process at constant conditions $\left(-27 /-27 /-27^{\circ} \mathrm{C}\right)$ and Process $3\left(-7 /-27 /-24^{\circ} \mathrm{C}\right)$, are shown in Figure 4.

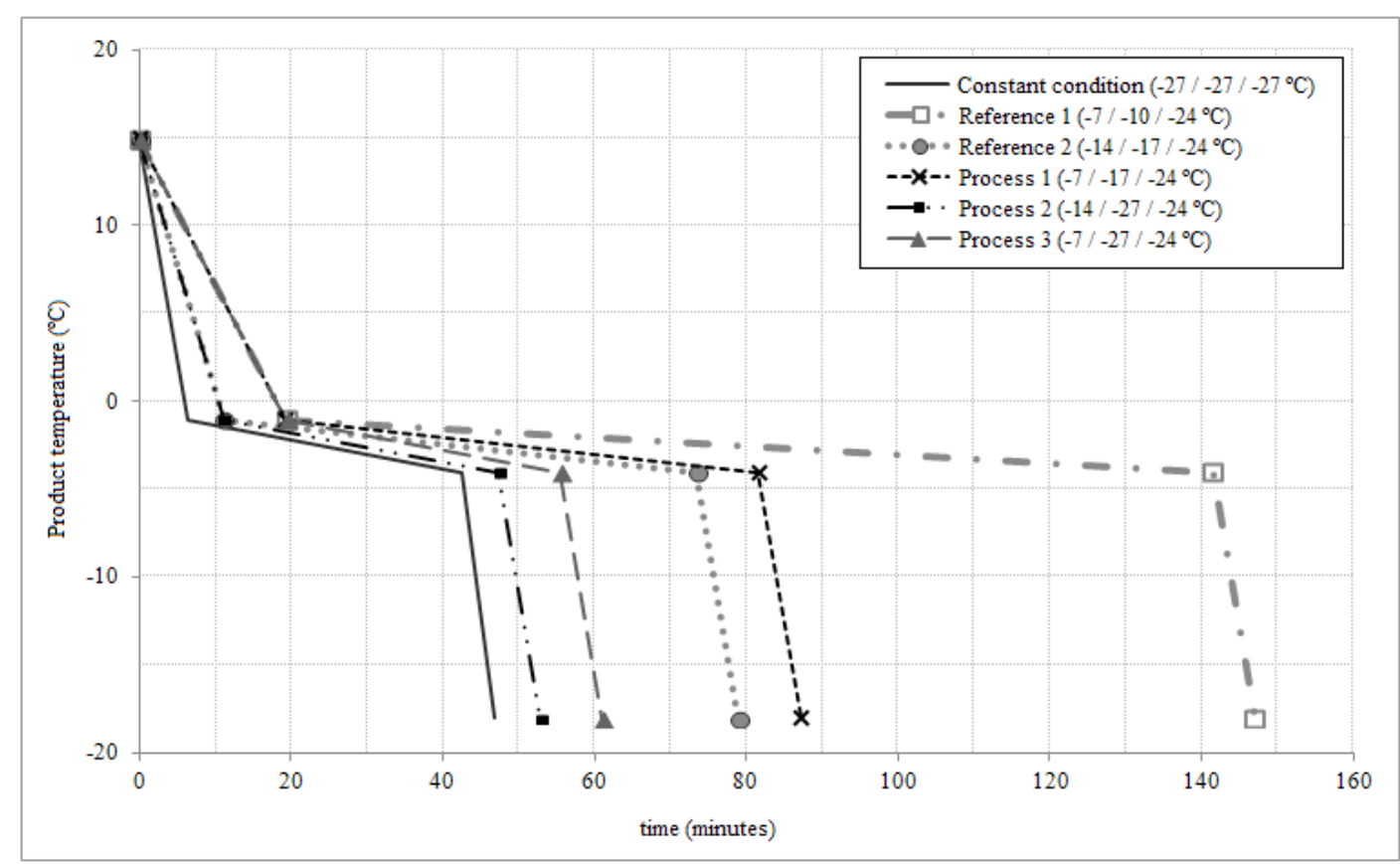

Figure 3. Representative temperature behavior history thru time at the five proposed processes and the process at constant conditions $\left(-27 /-27 /-27^{\circ} \mathrm{C}\right)$.

Table 2. Comparison between processes using different operating conditions modified per stage, regarding Reference $1(\Delta \mathrm{t} 1$ and $\Delta \mathrm{E} 1)$ and Reference $2(\Delta \mathrm{t} 2$ and $\Delta \mathrm{E} 2)$.

\begin{tabular}{ccccccc}
\hline & $\mathrm{t}(\mathrm{min})$ & $\Delta \mathrm{t} 1(\mathrm{~min})$ & $\Delta \mathrm{t} 2(\mathrm{~min})$ & $\mathrm{E}(\mathrm{kW} \mathrm{h})$ & $\Delta \mathrm{E} 1(\mathrm{~kW} \mathrm{~h})$ & $\Delta \mathrm{E} 2(\mathrm{~kW} \mathrm{~h})$ \\
\hline Ref. $1\left(-7 /-10 /-24^{\circ} \mathrm{C}\right)$ & 146.9 & - & +68.0 & 2.27 & - & -0.19 \\
Ref. 2 $\left(-14 /-17 /-24^{\circ} \mathrm{C}\right)$ & 79.0 & -68.0 & - & 2.46 & +0.19 & - \\
Proc. $1\left(-7 /-17 /-24^{\circ} \mathrm{C}\right)$ & 87.1 & -59.8 & +8.2 & 2.42 & +0.14 & -0.05 \\
Proc. 2 $\left(-14 /-27 /-24^{\circ} \mathrm{C}\right)$ & 52.9 & -94.1 & -26.1 & 2.85 & +0.57 & +0.39 \\
Proc. 3 $\left(-7 /-27 /-24^{\circ} \mathrm{C}\right)$ & 61.0 & -85.9 & -17.9 & 2.80 & +0.53 & +0.34 \\
\hline
\end{tabular}


Table 3. Percentage variations on process time $(\Delta \mathrm{t} \%)$ and energy consumption $(\Delta \mathrm{E} \%)$ for the simulated processes using operational conditions modified per stage, comparing with global process at constant conditions $\left(-27 /-27 /-27^{\circ} \mathrm{C}\right)$.

\begin{tabular}{|c|c|c|c|c|c|c|c|c|}
\hline & \multicolumn{2}{|c|}{ Pre-cooling } & \multicolumn{2}{|c|}{ Freezing step } & \multicolumn{2}{|c|}{ Sub-cooling } & \multicolumn{2}{|c|}{ Sum of stages } \\
\hline & $\Delta \mathrm{t} \%$ & $\Delta \mathrm{E} \%$ & $\Delta \mathrm{t} \%$ & $\Delta \mathrm{E} \%$ & $\Delta \mathrm{t} \%$ & $\Delta \mathrm{E} \%$ & $\Delta \mathrm{t} \%$ & $\Delta \mathrm{E} \%$ \\
\hline Ref. $1\left(-7 /-10 /-24^{\circ} \mathrm{C}\right)$ & +204.9 & -33.0 & +237.0 & -23.2 & +28.5 & -3.7 & +213.6 & -23.6 \\
\hline Ref. $2\left(-14 /-17 /-24^{\circ} \mathrm{C}\right)$ & +75.6 & -24.2 & +72.0 & -17.0 & +28.5 & -3.7 & +68.5 & -17.3 \\
\hline Proc. $1\left(-7 /-17 /-24^{\circ} \mathrm{C}\right)$ & +204.9 & -33.0 & +72.0 & -17.0 & +28.5 & -3.7 & +85.9 & -18.9 \\
\hline Proc. $2\left(-14 /-27 /-24^{\circ} \mathrm{C}\right)$ & +75.6 & -24.2 & 0.0 & 0.0 & +28.5 & -3.7 & +12.8 & -4.4 \\
\hline Proc. $3\left(-7 /-27 /-24^{\circ} \mathrm{C}\right)$ & +204.9 & -33.0 & 0.0 & 0.0 & +28.5 & -3.7 & +30.2 & -5.9 \\
\hline
\end{tabular}

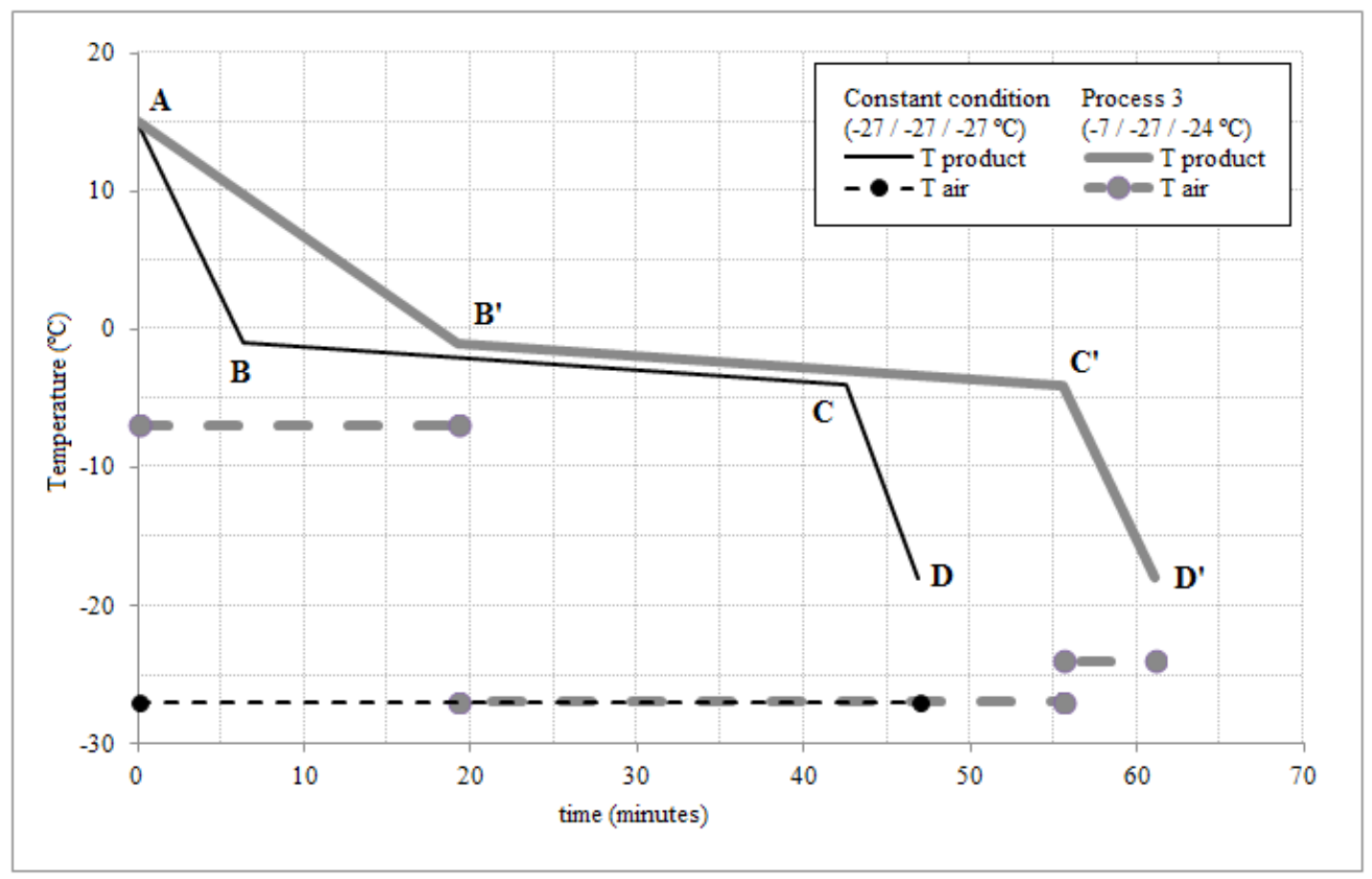

Figure 4. Comparison between representative behavior histories of air and product temperatures, for the process at constant conditions $\left(-27 /-27 /-27^{\circ} \mathrm{C}\right)$ and Process $3\left(-7 /-27 /-24^{\circ} \mathrm{C}\right)$.

Finally, it is interesting to observe that the methodology studied in the present work, and the discussions made, even if applied in a specific situation - modeled and well defined product and equipment -, can be extended to other products and equipment, with different properties, dimensions and requirements, without great loss to the analysis itself, so that the freezing strategy proposed can be largely applied in real situations, under slight alterations, when needed.

\section{Conclusions}

It was possible to propose a new strategy of operating conditions change in a simulated freezing process in tunnel, which allows the energy consumption decrease, keeping product's final quality, since it considers each stage of the process - pre-cooling, freezing step and sub-cooling - separately, and takes into account the requirements of each one of them in the choice of the operating conditions to be used.
Adequate operating conditions for freezing strawberries placed in boxes were chosen: air temperatures of $-7 /-27 /-24^{\circ} \mathrm{C}$, for pre-cooling, freezing step and sub-cooling, respectively. When such conditions were simulated, an energy consumption decrease of $5.9 \%$ was obtained, comparing to the process at single conditions $\left(-27 /-27 /-27^{\circ} \mathrm{C}\right)$. The process time showed increase of $30.2 \%$ without, however, affecting the freezing step, and consequently keeping the final product quality.

The chosen conditions have potential to be applied in real processes of other similar products, whose properties and requirements are close to the ones of the modeled strawberries.

Moreover, the strategy can be applied to different products and equipment, under suitable methodology alterations, to fit the desired process. Therefore, the strategy shows potential to be applied in different uses in the food industry, enabling intelligent ways to obtain energy economy without damaging the quality of the final products. 


\section{References}

Fellows, P. J. (2006). Congelamento. In P. J. Fellows, Tecnologia do processamento de alimentos: princípios e prática (2. ed., pp. 429-451). Porto Alegre: Artmed.

Heldman, D. R. (1992). Food freezing. In D. R. Heldman \& D. B. Lund (Eds.), Handbook of food engineering (pp. 277-315). New York: Marcel Dekker.

Lago, T. G. S. (2016). Estudo experimental e controle de um sistema de refrigeração com compressor de velocidade variável e válvula de expansão eletrônica (Dissertação de mestrado). Universidade Estadual de Campinas, Campinas.

Pham, Q. T. (1984). Extension to Planck's equation for predicting freezing times of foodstuff of simple shapes. International Journal of Refrigeration, 7(6), 377-383. http://dx.doi.org/10.1016/01407007(84)90008-2.
Resende, J. V. (2001). Análise do processo de transferência de calor para o congelamento de polpas de frutas em caixas comerciais (Tese de doutorado). Universidade Estadual de Campinas, Campinas.

Salvador, F. (1999). Projeto de um sistema de refrigeração industrial com 'set-point' variável (Dissertação de mestrado). Universidade de São Paulo, São Paulo.

Teruel, B. J. M. (2008). Tecnologias de resfriamento de frutas e hortaliças. Revista Brasileira de Agrociência, 14(2), 199-220.

Universidade Estadual de Campinas - UNICAMP. (2011). Tabela Brasileira de Composição Centesimal de Alimentos - TACO (4. ed). Campinas: UNICAMP/NEPA. Retrieved from https://www. unicamp.br/nepa/taco/contar/taco_4_edicao_ampliada_e_revisada. pdf?arquivo=taco_4_versao_ampliada_e_revisada.pdf

Zaritzky, N. E. (2000). Factors affecting the stability of frozen foods. In C. J. Kennedy (Ed.), Managing frozen foods (pp. 111-135). Cambridge: Woodhead Publishing Limited. 